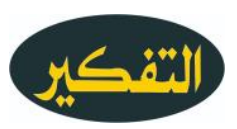

\title{
Tanggapan Mengenai Penggunaan Qawaid Fiqhiyyah Pada Fatwa MPU Aceh
}

\author{
Faisal \\ faisalfasya@iainlangsa.ac.id \\ Dosen Fakultas Syariah IAIN Langsa
}

\begin{abstract}
The Ulama of Aceh have obtained the highest degree in Acehnese society for centuries ago. The institution of ulama representing the people in Aceh as directed by qanun, was led by a qadhi and was assisted by four muftis in charge of four mainstream schools of thoughts, namely the Hanafy school, the Maliky school, the Shafi'i school and the Hanbaly school. The MPU of Aceh was founded through a long way process leading up to a large meeting of ulemas throughout Aceh at the end of June 2001. It is a merely independent institution that cannot be intervened by others as it is legally acknowledged in Aceh. Besides that, the MPU functions as partners along with the Aceh Government and the DPRA. One of the tasks of the MPU is to carry out research or translate and publish or istinbath of the law which is then documented as references to publish. It is also authorized to provide fatwas on issues relating to Islamic shari'ah which does not have provisions yet. The fatwas are enacted by looking at the arguments derived from Al Qur'an, hadith, ijma 'and qiyas, then are proceed to the qawaid fiqhiyyah and the opinions of the mu'tabarah scholars.
\end{abstract}

Keywords: MPU of Aceh, istinbath of the law, the qawaid fiqhiyyah

Abstrak: Para ulama Aceh telah mendapat derajat yang paling tinggi di dalam masyarakat Aceh mulai dari zaman dulu. Begitu juga dengan lembaga ulama sebagaimana yang terdapat di dalam qanun masyarakat Aceh yakni dipimpin oleh seorang qadhi dan di bantu oleh 4 orang mufti yang membidangi mazhab yang empat, yakni mazhab Hanafy, mazhab Maliky, mazhab Syafi'iy dan mazhab Hanbaly. MPU Aceh lahir dengan diawali jalan yang terjal dan berliku hingga diadakan musyawarah besar para ulama se Aceh pada akhir Juni 2001. MPU Aceh mempunyai legality yang tidak dapat diintervensi oleh pihak manapun dan sangat independen, dan bermitra dengan Pemerintah Aceh dan DPRA. Salah satu tugas MPU adalah melakukan penelitian atau melakukan penerjemahan dan menerbitkan atau istinbath hukum yang kemudian melakukan dokumentasi dan penertiban yang berhubungan dengan syari'at Islam dan memfatwakan permasalahan atau peristiwa yang belum ada ketetapan hukumnya dan fatwa

Jurnal At-Tafkir: Volume 13 Nomor 1 Tahun 2020

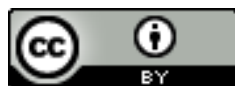

This work is licensed under a Creative Commons Attribution 4.0 International License 


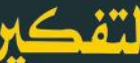

tersebut menjadi pijakan dan dasar bagi pemerintah untuk mentetapkan hukumnya dengan melihat kepada dalil-dalil alqur'an, hadis, ijma' dan qiyas, selanjutnya merujuk kepada qawaid fiqhiyyah dan pendapat para ulama yang mu'tabarah.

Kata Kunci: MPU Aceh, Istinbath Hukum, Qawaid Fiqhiyyah

\section{Pendahuluan}

Ilmu-ilmu yang berkaitan dengan penetapan hukum dalam lingkungan masyarakat muslim kurang dipahami dengan baik. Penetapan hukum sangatlah dibutuhkan dalam menjawab semua problematika baru yang banyak sekali bermunculan. Begitu banyaknya permasalahan yang muncul dan terjadi di tengah masyarakat secara tidak langsung melahirkan jumlah putusan hukum yang begitu banyak juga, penetapan hukum yang diputuskan dan menimbulkan masalah bagi para ulama fiqh, secara tidak langsung semakin sukar untuk dipahami dan diamalkan.

Islamic legal maxim bahasa lain dari qawaid fiqhiyyah dalam metode istinbath hukum sangat besar posisinya dan sangat penting. Qawaid fighiyyah adalah untuk memformulasikan kembali dalil-dalil yang sifatnya umum menjadi dalil bagi penetapan hukum(Arifandi, 2018).

Dengan kondisi yang demikian maka para ulama fiqh, termotivasi untuk mengumpulkan dan menyusun hukum-hukum yang sejenis, kemudian disederhanakan dengan dibuatkan susunan dalam kalimat yang singkat serta bersifat umum, untuk dapat membantu untuk memutuskan hukum-hukum yang baru.Kalimat yang sederhana dan bersifat umum tersebut kemudian dikenal dengan istilah qawa'id fiqhiyyah. Dengan itu, penguasaan yang mendalam terhadap ilmu khususnya qawa'id fiqhiyyaha kan mudah mengetahui dan memahami qawa'id Jurnal At-Tafkir: Volume 13 Nomor 1 Tahun 2020

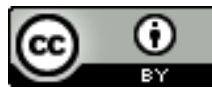

This work is licensed under a Creative Commons Attribution 4.0 International License 


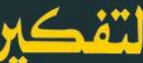

fiqhiyyah, dan akan lebih arif dan bijaksana dalam menetapkan hukum fiqih. Bahkan, kita akan lebih mudah dan memahami begitu juga menyikapi hukum pada masalah yang berhubungan dengan sosial, budaya, ekonomi dan politik.

Adapun tema atau kajiannya Qawaid fiqhiyyah adalah merupakan suatu kajian ilmu yang tidak berdiri sendiri, begitu juga dengan fiqih. Qawaid fiqhiyyah dapat dikatakan sebagai suatu derifasi dari fiqih atau hukum Islam. Dan permasalahan-permasalahan yang ada di dalam masyarakat dapat diselesaikan dengan adanya qawaid fiqhiyyah, baik itu dalam masalah ibadah, muamalah, munakahat dan jinayat atau dalam masalah-masalah hukum kontemporer.

Kemudian kalau diperhatikan dan diteliti lebih ke sisi substansinya maka menurut para ulama ushul qawaid fiqhiyyah, terbagi dua bagian saja; qaidah ashlaliyyah yang terdiri dari lima kaidah. Qaidah furu'iyyah yang juga terdiri dari banyak-banyak aspek yang berkaitan dengan ibadah, muamalah, munakahah, siyasah, maliyah dan lain-lain.

Dalam pembahasan kali ini, penulis hanya memfokuskan pada qawaid fiqhiyyah yang dijadikan sandaran oleh Majelis Permusyawaratan Ulama (MPU) Aceh dalam mengeluarkan fatwa atau pendapat pada tiga (3) permasalahan yang menjadi perhatian yang penting dan semua kalangan masyarakat menganggapnya sebagai hal sangat dharurat atau parah sekali, dan yang tidak hanya di Aceh namun warga masyarakat Indonesia. Kesatu, Penetapan hukum Game PUBG Tahun 2019 dan sejenisnya menurut Fiqh Islam, dan juga fatwa yang membahas dan mengalisa hal ikhwal kopi luwak dan juga penetapan hukum nikah siri.

Jurnal At-Tafkir: Volume 13 Nomor 1 Tahun 2020

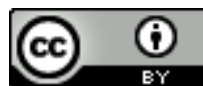

This work is licensed under a Creative Commons Attribution 4.0 International License 


\section{(1)}

\section{Profil Majelis Permusyawaratan Ulama (MPU) Aceh}

Pembahasan ulama dalam sejarah Aceh dari zaman dulu sampai sekarang telah membuktikan bahwa ulama mendapatkan tempat yang tinggi di hati masyarakat. Lembaga ulama sebagaimana yang terdapat di dalam qanun masyarakat Aceh yakni dipimpin oleh seorang qadhi dan di bantu oleh 4 orang mufti yang membidangi mazhab yang empat, yakni mazhab Hanafy, mazhab Maliky, mazhab Syafi'iy dan mazhab Hanbaly(MPU, 2020).

Pada waktu perang melawan Belanda dan Jepang, lembaga besar yang ada di Aceh tidak berwujud lagi, sehingga mengakibatkan munculnya muftimufti secara mandiri dan mengambil tempat dihati masyarakat. Sebenarnya diawal-awal kemerdekaan lembaga seperti ini sudah pernah terwujud dalam sebuah wadah besar yang bernama PUSA (Persatuan Ulama Seluruh Aceh). Tapi akhirnya PUSA juga mengalami pembubaran, yang selanjutnya lahir lembagalembaga lain, semisal Perti, Nahdatul Ulama, al Washliyah, Muhammadiyah dan lain-lain.

Awal sejarah terbentuk MPU Aceh adalah sepakatnya 'alim ulama di Aceh untuk mengadakan musyawarah akbar dengan diikuti oleh seluruh 'alim ulama yang di Aceh yaitu pada tanggal 17 Desember tahun 1965 dan dilaksanakan di Banda Aceh. Dalam musyawarah 'alim ulama tersebut lahirlah ide untuk mempersatukan para ulama yang ada di Aceh dan mempersatukan pendapatpendapat atau fatwa yang dikeluarkan oleh ulama tersebut dalam satu lembaga yang diakui dan dipercaya oleh pemerintah atau masyarakat yakni Majelis Permusyawaratan Ulama (MPU) Aceh dan angkat pada awal kepemimpinan Majelis Permusawaratan Ulama (MPU) Aceh diketuaioleh Syekh Abdullah Ujong Rimba(MPU, 2020).

Jurnal At-Tafkir: Volume 13 Nomor 1 Tahun 2020

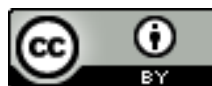

This work is licensed under a Creative Commons Attribution 4.0 International License 


\section{(1)}

Dan dalam musyawarah itu juga dibentuk beberapa unsur yang ada terdiri dari unsur pimpinan, unsur badan pekerja, unsur komisi dan unsur panitia khusus. Ada 5 hak wewenang yang diberikan dalam lembaga MPU ini, seperti wewenang fatwa atau ifta', wewenang penelitian dan perencanaan, weweang pendidikan, pengajaran dan kebudayaan, weweang dakwah dan penertiban dan wewenang harta agama. Dalam hal wewenang ini sama juga pada lembaga MPU yang ada di dalam wilayah Kabupaten ataupun Walikota.

MPU secara inheren adalah MUI, walaupun pada dasarnya MPU di Aceh lebih dahulu lahir, namun dengan dikeluarkannya Keputusan Gubernur dengan nomor 038 pada tahun 1968, maka MPU berubah namanya menjadi Majelis Ulama Indonesia Provinsi Daerah Istimewa Aceh, dengan tetap diberikan hakhak kewenangan yang sesuai dengan MPU lama.

UU nomor 44 tahun 1999 mempunyai arti yang sangat besar bagi kedudukan MUI Aceh, seperti yang tercantum dalam pasal 9 ayat 1 dan 2. Yakni diberikan hak kewenangan bagi daerah untuk membentuk dan membuat sebuah badan atau lembaga yang terdiri anggotanya dari unsur ulama.

Dengan adanya UU nomor 1999 tersebut maka pada tahun 2000 lahirlah Perda Aceh nomor 3 tahun 2000, dimana Perda tersebut menyatakan tentang pembentukan organisasi dan tatakerja pada lembaga yang didalamnya para ulama yakni MPU Aceh Darussalam dan Perda Aceh nomor 43 tahun 2001 yang merubah Perda Aceh tahun 2000 yakni pembentukan organisasi dan tatakerja lembaga yang didalamnya terdapat para 'alim ulama yakni MPU Aceh.

Akhir Juni 2001 ada diadakan suatu musyawarah besar untuk para ulama se Aceh pada tanggal 2 s/d 5 Rabi'ul Akhir $1422 \mathrm{H}$ yakni tahun $2001 \mathrm{M}$ di Banda Aceh demi memililh kepengurusan MPU prov. Aceh. Adapun lembaga MPU ini Jurnal At-Tafkir: Volume 13 Nomor 1 Tahun 2020

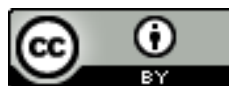

This work is licensed under a Creative Commons Attribution 4.0 International License 


\section{$y<$}

terbentuk pada 17 Ramadhan tahun 1422 H. MPU Aceh mempunyai legality yang tidak dapat diintervensi oleh pihak manapun dan sangat independen, dan dengan Pemerintah Aceh dan DPRA sebagai mitra kerja untuk masa khidmat 2001-2006.

Ketika ada UU nomor 112006 maka dapat memperkuat kedudukan MPU itu sendiri yang bahwa MPU adalah mitra dan sejajar dengan pemerintah Aceh dalam menyelenggarakan pemerintahan dan pembangunan, terutama pembangunan syariat Islam.

\section{Visi dan Misi MPU Aceh}

Visi:

"Terwujudnya peran ulama dalam pembangunan berbasis syariat Islam" Misi :

1. Memberikan masukan, pertimbangan, bimbingan, nasehat dan saran dalam penentuan kebijakan daerah, serta pemantauan terhadap pelaksanaan kebijakan daerah;

2. Melakukan pengawasan terhadap penyelenggaraan pemerintahan, kebijakan daerah berdasarkan syariat Islam;

3. Menetapkan fatwa;

4. Menggagas dan berkontribusi dalam penyusunan dan pengawasan qanun;

5. Mendorong pelaksanaan syariat Islam dalam seluruh aspek kehidupan masyarakat dan mencegah timbulnya perbuatan kemungkaran;

6. Melaksanakan pembinaan sumber daya keulamaan di Aceh;

7. Melakukan penelitian, pengembangan, penerjemahan, penerbitan dan pendokementasian terhadap naskah-naskah yang berkenaan dengan syariat Islam(MPU, 2020).

Jurnal At-Tafkir: Volume 13 Nomor 1 Tahun 2020

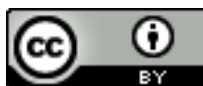

This work is licensed under a Creative Commons Attribution 4.0 International License 


\section{بـ}

\section{Tugas dan Fungsi MPU Aceh}

Melakukan penelitian atau melakukan penerjemahan dan menerbitkan yang kemudian melakukan dokumentasi terhadap naskah-naskah yang berhubungan dengan syari'at Islam. Dan melahirkan kader-kader ulama muda ini adalah tugas serta fungsinya MPU. Pada pemerintah Aceh akan memberikan saran baik masukan atau pertimbangan dan juga akan menerapkan kebijakankebijakan yang berdasarkan falsafah rakyat Aceh dan berdaulat Islam.

Sedangkan salah satu fungsi MPU adalah berfungsi untuk menetapkan atau memfatwakan sesuatu permasalahan atau peristiwa yang belaum ada ketetapan hukumnya dan fatwa tersebut manjadi pijakan dan dasar bagi pemerintah untuk mentetapkan hukumnya.Sesuai dengan uu no. 11 tahun 2006 pemerintahan Aceh(MPU, 2020).

Adapun kewenangan yang diberikan kepada MPU Aceh adalah salah satunya menyampaikan akan fatwa baik diminta ataupun tidak diminta, dalam berbagai hal seperti pembinaan masyarakat, dan ekonomi atau segala permasalahan yang ada pada masyarakat yang beragama Islam atau non muslim(MPU, 2020).

\section{Istinbath hukum}

Istinbath hukum adalah menemukan, menciptakan ini mkan secara etimologi atau secara bahasa. Sedangkan kalau kita artikan istinbath hukum adalah suatu proses yang ditempuh oleh seorang yang sudah dikategorikan mujtahid untuk menetapkan suatu hukum dan dengan cara ijtihad, inilah yang dikatakan istinbath kumu menurut terminology atau menurut istilah. Kemudian kata hukum adalah suatu putusan atau ketetapan, yang dalam kamus bahasa

Jurnal At-Tafkir: Volume 13 Nomor 1 Tahun 2020

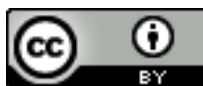

This work is licensed under a Creative Commons Attribution 4.0 International License 


\section{1}

Indonesia sebagi suatu kaidah, peraturan atau ketentuan. Sedangan menurut terminology adalah peraturan dan ketetntuan yang berdasarkan syariat Islam dan berkenaan dengan kehidupan(Muhammad Asadurrahman, 2019).

Adapun yang menjadi fokus istinbath adalah sumber hukum yakni dalil al Qur'an dan hadis, maka penggalian hukum dan penetapan hukum yang berasal dari kedmua sumber dalil tersebut itulah yang disebut istinbath. Dalam Islam terhadap penetapan hukum yang menjadi sumber rujukan pertamanya al Qur'an dan Hadist Nabi yang menjadi sumber pendukungnya adalah ijtihad yang dikeluarkan oleh para ulama. Oleh karena itu dalam mengistinbath hukum haruslah berpijak pada al Qur'an dan Hadist Nabi.

Ada dua macam cara pendekatan dalam menggali hukum atau thuruq al istinbath dari nash, yaitu dengan pendekatan makna (thuruq al ma'nawiyah) dan pendekatan lafadh (thuruq al lafdhiyah). Pendekatan maknawiyah yakni menggunakan seperti qiyas, istihsan, istislahi, masalahah mursalah untuk menarik kesimpulan hukum pada bukan langsung nash.

Tujuan diadakannya istinbath hukum yakni untuk dapat menetapkan hukum pada setiap perbuatan atau perkataan mukallaf dengan cara meletakkan qaidah-qaidah hukum yang ditetapkan.

Pada masa sekarang ini, berbagai macam cara metode atau konsep dalam menetapkan ijtihad ataupun fatwa dan dalam semakin berkembang dalam pengistinbat hukum. Pembahasan tentang qaidah-qaidah hukum akan membuat kita mengetahui perbedaan pendapat yang terjadi diantara para uqaha dalam ranah menentukan suatu hukum dan dapat kita pahami hukum-hukum mana yang ditunjuk oleh nash. Jika seorang fuqaha menetapkan hukum syari'ah atas

Jurnal At-Tafkir: Volume 13 Nomor 1 Tahun 2020

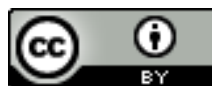

This work is licensed under a Creative Commons Attribution 4.0 International License 


\section{rit}

perbuatan seorang mukallaf, maka ia sebenarnya telah meng-istinbath-kan hukum dengan sumber hukum yang terdapat di dalam qaidah-qaidah ushuliyah yang telah dirintis oleh ahli ushul fiqh(Syamsul Bahri, 2011).

\section{Pengertian Qawa'id Fiqhiyyah}

Qawa'id Fiqhiyyah memiliki pengertian tersendiri dan terdiri dari dua kosakata yakni qawaid dan fiqhiyyah, masing-masing mempunyai arti tersendiri. Misalkan, kata qawa'id (قواعد) dalam bentuk kata jamak, sedangkan kata mufradnya (satuannya) adalah qa'idah (قاعدة) yang berarti; asas, landasan, dasar atau fondasi sesuatu. Selanjutnya makna dari pada qaidah ini ada yang bersifat hissi dan ada yang bersifat maknawi. Contoh dari pada hissi seperti fondasi bangunan rumah, sedangkan contoh ma'nawi, seperti ushuluddin (dasar agama)(Azhari, 2015). Artinya:

"dan (ingatlah), ketika Ibrahim meninggikan (membina) dasar-dasar Baitullah bersama Ismail (seraya berdoa): "Ya Tuhan Kami terimalah daripada Kami (amalan kami), Sesungguhnya Engkaulah yang Maha mendengar lagi Maha Mengetahui". (2S. alBaqarah: 127)

Kata fiqhiyyah berasal dari kata figh yang ditambah dengan huruf " ya nisbah". Ya nisbah ini berfungsi sebagai penjenisan, atau penyandaran suatu objek kepada objek yang lain. Secara etimologi maksud fiqh adalah pengetahuan, pemahaman, atau memahami, maksudnya kita memahami perkataan atau pembicaraan seseorang(Azhari, 2015). Artinya:

"....mengapa tidak pergi dari tiap-tiap golongan di antara mereka beberapa orang untuk memperdalam pengetahuan mereka tentang agama...”. (2S. at Taubah: 122)

Jurnal At-Tafkir: Volume 13 Nomor 1 Tahun 2020

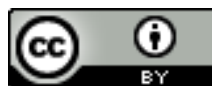

This work is licensed under a Creative Commons Attribution 4.0 International License 


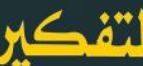

Dari ayat di atas kita mengertibahwa bahwa pengertian qaidah adalah dasar, asas atau pondasi, tempat yang diatasnya berdiri suatu bangunan.Sedangkan pengertian fiqh berarti ilmu agama (syariah). Dengan demikian dapat disimpulkanbahwa qawa'id fiqhiyyah secara etimologi adalah dasardasar, pondasi-pondasi atau asas-asas yang berhubungan dengan permasalahan hukum (fiqh). Kemudian secara terminologi (istilah), para ulama berbeda pandangan dalam memberikan pengertian qawa'id fiqhiyyah, diantaranya menjelaskan dengan makna yang luas, sebagian yang lain dengan makna yang sempit. Meski demikian jika dilihat dari konteks definisinya, secara substansi definisi tersebut memiliki titik kesamaan.

Menurut al Jurjani (w. 1816 H) memberikan definisi qawa'id sebagai undang-undang yang mencakup seluruh bagian-bagiannya dan bersifat kulli (menyeluruh/general). Adapun Imam Asy Suyuthi mendefinisikan qawa'id adalah sebagai sebuah hukum yang meliputi seluruh bagian-bagiannya dan ia bersifat kulli (menyeluruh/gerenal), sedangkan menurut al Taftazani (w. $791 \mathrm{H}$ ) yang dikutip oleh AdeDedi Rohayana, mendefinisikan qawa'id sebagai hukum yang dapat diaplikasikan kepada seluruh juz'inya dan ia bersifat universal (kulli), dimana persoalan juz'i (bagian) tersebut dapat diidentifikasi daripadanya(Azhari, 2015).

Perlu diketahui dari beberapa pendapat dia atas, Ali Ahmad al-Nadwi sebagaimana yang dikemukakan oleh Fathhurraman Azhari, mengkompromikan pemahaman tentang qawaid fiqhiyyah dalam pengertian bahwa hukum-hukum syara' yang bersifat umum dan berbagai peristiwa dan ruanglingkupnya masuk kedalamnya dan ia adalah dasar fiqh(Azhari, 2015).

Jurnal At-Tafkir: Volume 13 Nomor 1 Tahun 2020

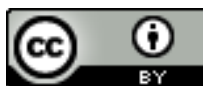

This work is licensed under a Creative Commons Attribution 4.0 International License 


\section{(1)}

Dimaklumi dari beberapa definisi yang dikemukakan di atas, sangat jelas bahwa qawa'id itu bersifat menyeluruh meliputi bagian-bagian yakni dapat diterapkan kepada juz'i-juz'inya (bagian-bagiannya). Jadi dapat kita simpulkan bahwa pengertian qawa'id fiqhiyyah adalah hukum yang bersifat mayoritas dan mencakup sebagian besar juz'i (bagian-bagiannya) supaya dapat diketahui hukum-hukumnya. Jika dilihat dari definisi yang ada secara garis besar ulama terbagi dua kelompok dalam mendefinisikan qawa'id fiqhiyyah, ini berdasarkan kenyataan bahwa ada sebagian ulama yang mendefinisikan qawa'id fiqhiyyah sebagai sesuatu yang bersifat kulliyat (universal) dan sebagian yang lainnya mendefinisikannya sebagai sesuatu yang bersifat aktsariyyah (mayoritas).

Perbedaan pendapat ini berangkat dari perbedaan perspektif, ulama yang berpendapat bahwa qawa'id fiqhiyyah itu sifatnya kulli karena berpatokan pada pengecualian yang terdapat dapat qawa'id fiqhiyyah itu sifatnya relatif dan tidak banyak. Dan ulama pada kelompok ini sangat berpandang kepada pengecualian (istitna') itu tidak mempunyai hukum, sehingga tidak mengurangi sifat kulli qawa'id fiqhiyyahnya. Sedangkan ulama yang berpendapat qawa'id fiqhiyyah itu sifatnya mayoritas (aghlabiyyah atau aktsariyyah), yaitu memang pada kenyataannya seluruh qawa'id fiqhiyyah itu mempunyai pengecualian, sehingga penyebutan universal (kulli) terhadap qawa'id fiqhiyyah kuranglah tepat adanya.

Selanjutnya dapat dilihat bahwa para ulama sebenarnya sepakat dalam masalah qawa'idfiqhiyyah memiliki pengecualian (istitsna'), akan tetapi mereka berbeda dengan istitsna' yakni apakah berpengaruh terhadapa keumuman qawa'id fiqhiyyah atau tidak?. Ada satu kata kunci yang terdapat pada pengertian tersebut

Jurnal At-Tafkir: Volume 13 Nomor 1 Tahun 2020

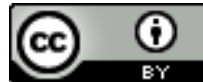

This work is licensed under a Creative Commons Attribution 4.0 International License 


\section{C.1}

yaitu kalimat mayoritas namun bukan menyeluruh.Karena dalam qawa'id fiqhiyyah banyak sekali kasus hukum yang menjadi pengecualian dari qawa'id fiqhiyyah yang ada, sehingga sifatnya mayoritas, yakni banyak hukum yang masuk kedalamnya namun tidak secara keseluruhan hukum.Sifat menyeluruh pada dasarnya telah dimiliki oleh ilmu ushul fiqih memang sifatnya mencakup keseluruhan, maka dapat dipahami bahwa didalam hukum Islam itu ada dua macam qaidah, yaitu qawa'id ushuliyyah dan qawa'id fiqhiyyah.

\section{Pemakaian Qawaid Fiqhiyyah pada Fatwa MPU Aceh}

Salah satu unsur yang harus dalam sebuah ketetapan fatwa MPU Aceh adalah memuat qawa'id fiqhiyyah dan menjadi salah satu dasar hukum yang akan ditetapkan dalam suatu fatwa hukum.

Adapun fatwa-fatwa yang dikemukkan didalam makalah ini adalah hasil fatwa yang dikeluarkan oleh MPU Aceh dan telah dipublikasikan di dalam webset miliknya MPU Aceh dalam beberapa tahun terakhir. Namun demikian banyak sekali fatwa-fatwa yang dikeluarkan oleh MPU Aceh yang sangat ringkas dengan tidak memuat qawaid fiqhiyyah, padahal qawaid fiqhiyyah sebagaimana kita ketahui adalah salah satau dasar hukum yang sangat urgen dalam menetapkan suatu hukum.

\section{Fatwa Hukum Game PUBG}

a. Paparan Umum Game PUBG (Player Uknown's Battlegrounds)

Paparan umum tentang game PUBG ini adalah suatu permainan yang dijalankan secara daring atau dalam jaringan dan dimainkan dengan telepon selular atau pc dalam bentuk peperangan(Winarto, 2020).

Jurnal At-Tafkir: Volume 13 Nomor 1 Tahun 2020

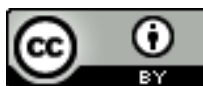

This work is licensed under a Creative Commons Attribution 4.0 International License 


\section{بـ}

Sudah dimaklumi bahwa game PUBG ini dijalankan dan dikembangkan oleh sebuah perusahaan corporation studio internal dari Bluehole pengembang PlayerUnknown's Battlegrounds (PUBG).

Untuk diketahui bahwa sejarah Perusahaan ini sebenarnya didirikan pertama sekali dengan nama Ginno Games. Dan pada tanggal 27 Januari 2015, Bluehole melakukan akuisisi Ginno Games, dengan penjualannya ditutup pada tanggal 27 Maret 2015. Kemudian Ginno Games mengganti nama perusahaan dengan Bluehole Ginno Games pada bulan Mei 2015. Pada tahun 2017 game PUBG mengalami kesuksesan sehingga Bluehole Ginno Games mengganti namanya kembali menjadi PUBG Corporation pada September 2017. Dan pada akhir 2017 didirikanlah markas kantor keduanya yang berlokasi di Madison, Wisconsin. Dan karena kesuksesan yang dicapai oleh perusahan ini, maka saat ini mereka berencana membangun dua kantor baru yang mereka tetapkan lokasinya di Jepang dan di Eropa(Bakri, 2019).

Pada dasarnya game ini didasarkan oleh kumpulan mod yang dibuat oleh Brendan Greene atau yang dikenal juga PlayerUnknown, dan ispirasi yang didapat oleh Brendan Greene ini adalah dari film-film yang dibuat oleh jepang dengan judul Battle Royale, lalu mod ini dikembangkan menjadi sebuah game yang mandiri dan Brendan Greene sendiri sebagai pengarah pada tim kreatifnya (creative direction).

b. Proses Penetapan Hukum Game PUBG oleh MPU Aceh

Proses penetapan hukum terhadap game PUBG adalah setelah dilakukan kajian terukur dalam melihat dalil-dalil, fiqh, informasi teknologi dan psikologi maka MPU mengelurkan hukum terhadap game PUBG adalah haram.

Jurnal At-Tafkir: Volume 13 Nomor 1 Tahun 2020

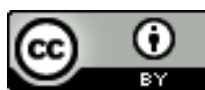

This work is licensed under a Creative Commons Attribution 4.0 International License 


\section{الثن:}

Game yang dapat masuk kedalam pandangan pemain lain adalah game PUBG dan PUBG merupakan termasuk salah satu game yang bisa membuat para penggunannya bermain dengan sudut pandangan orang lain. Adapun keinginan pemain game ini sebagaimana kita tahu itu berbda satu sama lainnya, namun pada dasarnya mereka pemain adalah ingin mencari sensasi dan keasyikan dala bermain game PUBG ini, karena game ini diciptakan sebaik mungkin dan semirip-miripnya dengan realita yang sebenarnya. Tapi sayangnya game ini mengarahkan kepada pemainnya adalah sikap dan mentalnya kearah yang tidak baik dan menentang dengan tatakrama dan akhlak atau prilaku yang dalam agama kita menomor satukan. Dan menjauhkan diri si pemain game ini dengan orang-orang sekitarnya apabila dia sudah asyik dan ketagihan dan bahkan sesansi yang didapat sangatlah sesuai dengan kenginan sipemain tersebut.

Penetapan hukum haram terhadap game PUBG adalah dengan didasari pada 4 kategori, ini yang disampaikan oleh Prof. Muslim Ibrahim, MA (sekarang sudah alm). Adapun 4 kategori tersebut adalah: PUBG adalah game yang memiliki unsur kekerasan dan kebrutalan, game PUBG memeiliki pengaruh untuk merubah prilaku-prilaku penmainnya nenjadi negatif, game PUBG dapat menimbulkan prilaku-prilaku yang agresif bagi pemainnya dan dapat menjadikan kecanduan pada level berbahaya bagi pemainnya/pengguna, dan yang terakhir game PUBG mengandung unsur penghinaan bagi simbol-simbol agama Islam.

Hasil kajian yang dilakukan oleh seluruh anggota MPU Aceh dan ditambah para pakar dalam bidang fiqh, informasi tekhnologi dan psikologi maka disepakati bahwa game PUBG adalah game yang berpangkal pada kriminal, krisi moral dan psikologis dan yang pada akhirnya meresahkan masyarakat.

Jurnal At-Tafkir: Volume 13 Nomor 1 Tahun 2020

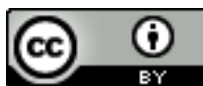

This work is licensed under a Creative Commons Attribution 4.0 International License 


\section{إن}

Bahkan Prof. Muslim Ibrahim, MA menambahkan bahwa penetapan hukum haram terhadap game PUBG bukan hanya mengacu pada terbuangnya waktu secara percuma dan sia-sia saja, tetapi besar akibat buruknya. Dan pengharaman game ini juga bukan hanya mengacu pada kesia-siaan waktu yang terbuang, tapi lebih kepada akibat buruk yang dihasilkan oleh game tersebut atau lebih besar mudharatnya dari pada kemashlahatannya.

Seperti pada sidang-sidang yang diselenggarakan oleh MPU Aceh lainnya yaitu ada beberapa risalah yang dipersiapkan dan di hadirkan beberapa tokoh atau pakar dalam setiap permasalahan yang diangkat untuk mencapai suatu putusan hukum dan akan dimasukkan dalam fatwa yang dikeluarkan oleh MPU Aceh. Khusus dalam masalah penetapan hukum game PUBG ini dilaksanakan oleh Panmus (Panitia Musyawarah) dibawah koordinator Lem Faisal, dan diketuai oleh Abiya Hatta, Sekretaris Tgk. M. Fajarul F dan empat anggota MPU lainnya. Adapun risalah yang dipersiapkan dan dipaparkan masingmasing oleh Prof. Muslim Ibrahim dari segi analisis hukum Islam, kemudian dari segi teknologi dan informasi oleh Teuku Farhan, SI.Kom, serta dari segi psikologi oleh pakar psikologi yakni ibu Yusniar, M.Si.

Dari berbagai kajian tersebut, MPU menyimpulkan bahwa orang yang memainkan game ini maka dia akan dengan mudah melakukan kekerasan, kriminal, sadisme, sehingga menurunkan kelembutan dan kemanusiannya pada dirinya. Dan terhadap mereka yang sudah kecanduan baiasanya mereka akan melakukan akan apa yang dalam kesehariannya seperti yang ada dalam game tersebut, sebagaimana halnya yang terjadi di negara Selandia Baru, dimana seorang laki-laki yang sudah kecanduan game tersebut yakni melakukan penembakan terhadap kaum muslimin yang sedang berada di salah satu masjid Jurnal At-Tafkir: Volume 13 Nomor 1 Tahun 2020

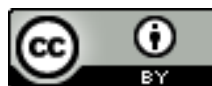

This work is licensed under a Creative Commons Attribution 4.0 International License 


\section{ب}

yang ada di negara Selandia Baru, sehingga banyak sekali korban dari pihak muslim yang meninggal dunia.

Kemudian, terhadap pembiaran anak-anak yang bermain game ini atau sejenisnya maka sama juga dengan mencetak dan mendidik mereka untuk menjadi mesin pembunuh yang sewaktu-waktu dapat diperintah atau keinginan sendiri karena telah dipenuhi akan kebencian terhadap Islam maka mereka akan melakukan hal-hal yang keji dan biadab seperti yang ada dalam geme tersebut. Bahkan dalam game ini yang menjadi target-target yang dimainkan adalah target yang diembelin simbol-simbol Islam, sehingga setiap pemainnya akan menimbulkan kebencian di dalam hatinya terhadap Islam seperti ditempatkan adanya bangunan yang sama dengan Ka'bah dan bangunan tersebut harus dihancurkan dan simbol-simbol Islam lainnya.

Guru besar UIN Ar Raniry Muslim Ibrahim, juga sangat meyakini akan akibat yang disebabkan oleh kecanduan terhadap game ini dan sejenisnya dan beliau juga meyakini bahwa hal yang diakibatkan oleh kecanduan game ini sama seperti kecanduan terhadap khamar atau ganja yang sudah jelas hukumnya yakni haram, "Bermain game ini mirip minum khamar. dan didalam al Quran telah dijelaskan bahwa khamar itu memang ada faedahnya, tapi kemafsadatan dan kemudhratannya jauh lebih besar atau banyak.

c. Dasar hukum yang dipakai MPU Aceh

Adapun dasar hukum yang dipakai oleh Majelis Permusyawaratan Ulama (MPU) Aceh tentang penetapkan hukum haram pada game PUBG (PlayerUnknown's Battlegrounds) adalah:

1. Surat an Nisa': 9;

Jurnal At-Tafkir: Volume 13 Nomor 1 Tahun 2020

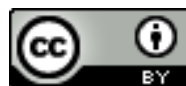

This work is licensed under a Creative Commons Attribution 4.0 International License 


\section{r}

Artinya: "dan hendaklah takut kepada Allah orang-orang yang seandainya meninggalkan dibelakang mereka anak-anak yang lemah, yang mereka khawatir terhadap (kesejahteraan) mereka. oleh sebab itu hendaklah mereka bertakwa kepada Allah dan hendaklah mereka mengucapkan Perkataan yang benar". (QS. an Nisa': 9)

2. Hadits;

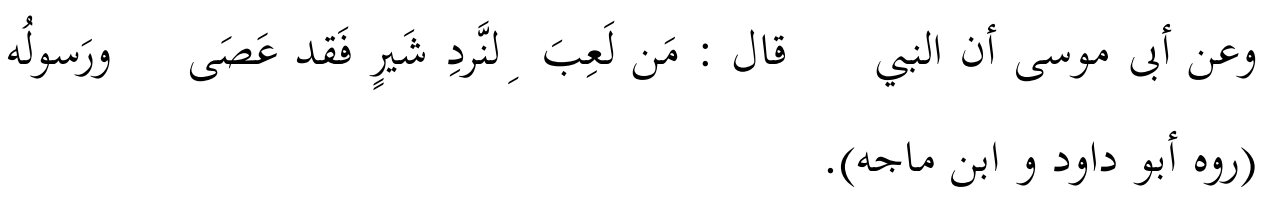

Artinya: "Dari Abi Musa bahwa Nabi saw., bersabda: Barang siapa yang bermain dengan dadu, ia sungguh telah maksiat kepada Allah dan Rasulnya". (HR. Abu Daud dan Ibnu Majjah)

3. Ijma' ulama.

4. Qiyas.

5. Qawa'id Fiqhiyyah;

$$
\text { الأصل في الأشياء الا حة حتى يدل الدليل على تحريم }
$$

Artinya: "Segala sesuatu yang ada pada dasarnya boleh, kecuali bila ada dalil yang mengharamkannya".

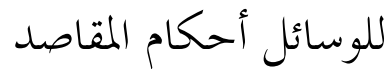

Artinya: Semua sarana suatu perbuatan hukumnya sama dengan tujuannya (perbuatan tersebut).

Jurnal At-Tafkir: Volume 13 Nomor 1 Tahun 2020

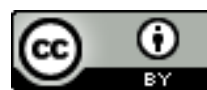

This work is licensed under a Creative Commons Attribution 4.0 International License 


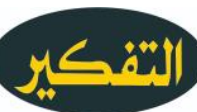

6. Pendapat Ulama;

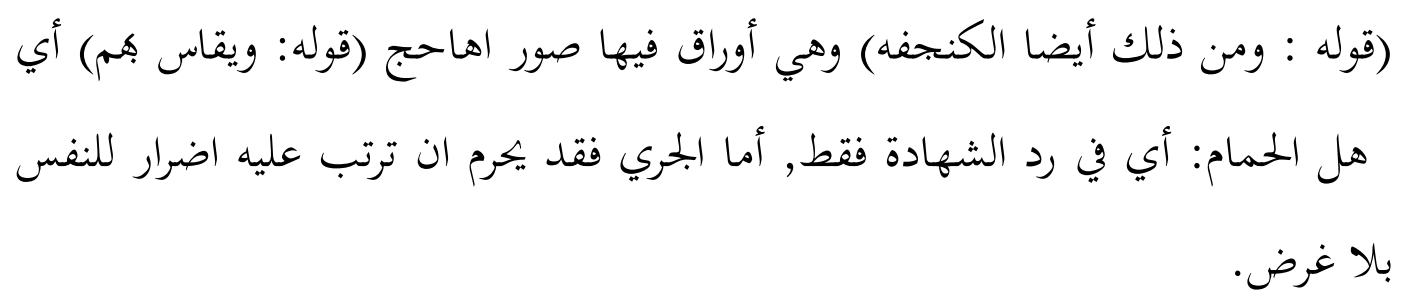

Artinya: "Berkata al Mallasi, termasuk bagian yang berpegang pada tebak-menebak adalah aljafah, yaitu kertas-kertas bergambar. Katanya lagi, diqiyaskan kepada mereka (orang-orang yang melakukan permainan menggunakan merpati), maksudnya pada sisi menolak kesaksian saja.Adapun permainan lari, kadang-kadang haram jika menimbulkan kemudhartatan diri sendiri dengan tanpa tujuan/faedah".

\section{Fatwa Hukum Kopi Luwak}

Fatwa ini dikeluarkan oleh MPU Aceh bertepatan dengan sidang dewan paripurna ulama yang ke 6, pada tanggal 4 s/d 6 Muharram 1433 H bertepatan 30 November s/d 02 Desember 2011 M.

Alasan MPU Aceh melakukan sidang paripurna terhadap kopi luwak ini adalah karena sudah sangat banyak para petani kopi untuk membudi daya kopi luwak ini dikarenakan pemasaran terhadap kopi luwak ini sangatlah menggiurkan dan dapat meningkatkan perekonomian masyarakat khususnya para petani kopi dan para konsumen kopi luwak pun sudah sangat banyak.

Dengan pertimbangan tersebut dan bahkan banyak sekali masyarakat yang bertanya dan meminta pertimbangan dari MPU Aceh untuk mengeluarkan hukum tentang mengkonsumsi kopi luwak tersebut.

Sebagaimana diketahui bahwa kopi luwak yang berasal dari kotoran musang (luwak), oleh karena itu menimbulkan diskusi yang mendalam dikalangan masyarakat, kemudian MPU Aceh merasa perlu mengeluarkan satu

Jurnal At-Tafkir: Volume 13 Nomor 1 Tahun 2020

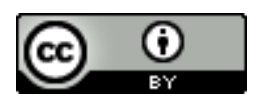

This work is licensed under a Creative Commons Attribution 4.0 International License 


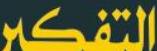

fatwa hukum tentang statusnya hukum kopi luwak, yaitu biji kopi luwak adalah mutanajjis (benda suci yang terkena najis) dan dengan syarat masih utuh serta bisa tumbuh jika ditanam dan penyuciannya mengikuti ketentuan-ketentuan syar`i. dan memproduksi dan memperjualbelikannya adalah hukumnya mubah (boleh). Terhadap hukum mengkonsumsinya adalah halal dengan syarat telah diolah dengan ketentuan syar`i(MPU Aceh, 2011).

Adapun fatwa MPU Aceh akan kopi luwak ini berdasarkan:

1. Al Qur'an

2. Hadist

3. Qaidah Fiqhiyyah

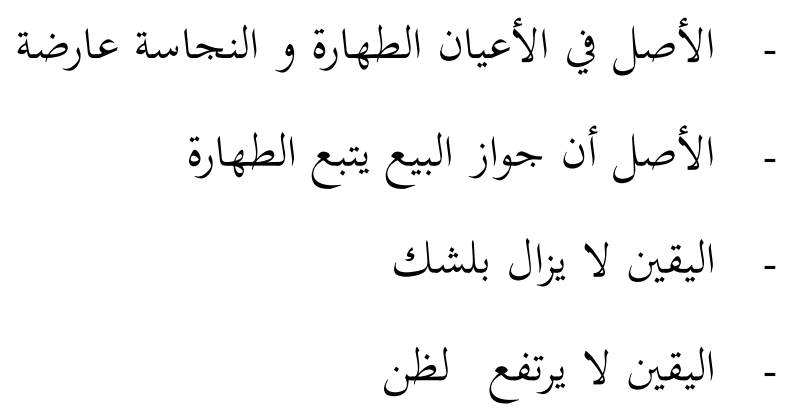

4. Pendapat Ulama:

Banyak para ulama yang berpendapat sebagaimana yang dikeluarkan oleh MPU Aceh tentang kopi luwak, seperti Muhammad Bakar Ismail, Muhammad Az Zuhaili. Rawwas Qal'ahjie, dengan kitabnya Mu'jam Lughah al Fuqaha'. Mahmud Abdul Lathif Uwaidhah, Taqiyuddin al Husaini, Kifayatul Akhyar, kemudian Imam Nawawi, ausu'ah al Qawa'id al Fiqhiyah karangan Muhammad Shidqi al Burnu, Muhammad 'Amim al Ihsan al Barkati, Wahbah Zuhaili, tentang Kopi Luwak di dalam fatwa yang dikeluarkan MUI dengan nomor 7 pada tahun 2010(MPU Aceh, 2011).

Jurnal At-Tafkir: Volume 13 Nomor 1 Tahun 2020

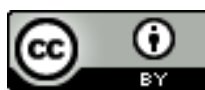

This work is licensed under a Creative Commons Attribution 4.0 International License 


\section{r}

\section{Fatwa Nikah Siri}

Fatwa ini dikeluarkan oleh MPU Aceh setelah dilakukannya sidang paripurna I, yang dilaksanakan pada tanggal 5 s/d 7 Jumadil Akhir 1431 H / 19 s/d 21 Mei 2010 M, dan setelahmenimbang dengan seksama bahwa akhir-akhir ini banyak praktek nikah siri dan semakin gencarnya pembicaraan tentang rancangan aturan yang mengenakan sanksi kepada pelaku nikah siri; dan bahwa hal tersebut telah meresahkan masyarakat karena belum ada kepastian hukum syari'at tentang itu, oleh karena itu MPU memandang perlu menetapkan fatwa tentang hukum nikah siri.

Suatu pernikahan yang dilakukan tidak didaftarkan pada KUA kecamatan dan bukan dihadapan petugas pencatat nikah maka ini menurut MPU adalah nikah siri.

Dalam pandangan Syara', nikah siri tersebut ada yang sah dan ada yang tidak sah;

a. Nikah Siri yang sah adalah Nikah Siri yang lengkap rukun dan syaratsyaratnya;

b. Nikah Siri yang tidak sah adalah nikah siri yang tidak sempurna rukun dan syarat syaratnya.

Adapun fatwa tentang nikah sirri ini didasari pada(MPU, 2010):

1. Al Qur'an

2. Hadist

3. Qaidah Fiqhiyyah

a. الضرر يزال

Jurnal At-Tafkir: Volume 13 Nomor 1 Tahun 2020

(c) (i)

This work is licensed under a Creative Commons Attribution 4.0 International License 


\section{$1<$}

Perlakuan sebagian besar suami yang melangsungkan nikah siri dapat menyusahkan atau memudharat isteri dan anak. Seandainya, tidak ada dalil dalil lain yang menyuruh catat dan permaklumkan aqad nikah, kaidah fiqhiyyah di ataspun sudah cukup adanya.

b. Menutup jalan menuju kepada larangan ( سد الذريعة )

Untuk menutup jalan kepada kejahatan seperti tidak membayar nafkah tidak membiayai pendidikan anak dan sebagainya itulah sebetulnya perlu adanya pencatatan nikah.

4. Peraturan Perundang-undangan:

a. Peraturan tentang perkawinan yakni UU Nomor 1 Tahun 1974.

b. Peraturan tentang Adm Kependudukan yakni UU Nomor 23 Tahun 2006.

c. Kompilasi Hukum Islam.

d. Dan memperhatikan pendapat para ulama, seperti:

1. Lembaga fatwa al Azhar Kairo memperhatikan Akte Nikah dalam berfatwa.

2. Mufti negara Mesir dalam melandaskan fatwanya kepada Akte Nikah.

\section{Penutup}

Dari contoh fatwa yang penulis teliti dan dikeluarkan oleh MPU Aceh pada tahun 2019 dengan nomor 3 tahun 2019 terhadap penetapan hukum game PUBG (PlayerUnknown's Battlegrounds), fatwa tentang kopi luwak dan fatwa tentang nikah siri, dapat kita breakdown bahwa fatwa hukum yang dilakukan

Jurnal At-Tafkir: Volume 13 Nomor 1 Tahun 2020

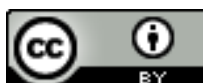

This work is licensed under a Creative Commons Attribution 4.0 International License 


\section{1)}

oleh MPU Aceh telah dilakukan dengan tata cara yang baik dan telah sesuai dengan prosedural atau tata tertib dalam mengeluarkan/mengistinbath hukum yang telah dikluarkan oleh pemerintah Aceh dalam bentuk Perda atau Qanun. Seperti dalam hal mengeluarkan fatwa, MPU Aceh akan memberikan fatwa baik diminta ataupun tidak, dan sebelum mengeluarkan fatwanya maka MPU Aceh akan memanggil para-para pakar dalam permasalahan yang akan dikeluarkan fatwa. Kemudian MPU Aceh mengeluarkan fatwanya sesuai dengan dalil-dalil atau dasar hukum dalam meng-istinbath-kan hukum atau fatwanya tersebut.

Dan dapat kita katakan bahwa fatwa yang dikeluarkan MPU Aceh berbeda dengan yang dikeluarkan oleh MUI diantaranya yakni fatwa MPU Aceh dalam hal meng-istinbath-kan atrau mengeluarkan pendapat hukum akan lebih merujuk kepada pendapat-pendapat ulama terdahulu atau lebih condrong merujuk kepada kitab kuning, terlebih kepada yang bermazhab Syafi'i.

Namun demikian, penulis berpendapat bahwa hasil fatwa yang dikeluarkan oleh MPU Aceh masih kurang jelas dalam memaparkan dasar hukum pegangan fatwa, seperti dalil al Qur'an, hadis ijma' qiyas dan qawaid fiqhiyyah.

Wallahu alam bis sawwab.

\section{DAFTAR PUSTAKA}

Arifandi, F. (2018). Qawaid Fiqhiyyah Sebagai Formulasi Hukum (Faqih (ed.); 1st ed.). Rumah Fiqih Publishing.

Azhari, F. (2015). Qawaid Fiqhiyyah Muamalah (Pertama). Lembaga Pemberdayaan Kualitas Ummat (LPKU) Banjarmasin.

Bakri. (2019). fatwa-haram-game-pubg. Serambinews.Com. https://aceh.tribunnews.com/2019/06/25/fatwa-haram-game-pubg

MPU. (2010). Keputusan MPU Aceh Tahun 2010. Mpu.Acehprov.Go.Id/. https://mpu.acehprov.go.id/uploads/NOMOR_Ol_TAHUN_2010_NIKAH_SI Jurnal At-Tafkir: Volume 13 Nomor 1 Tahun 2020

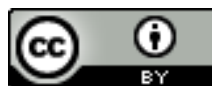

This work is licensed under a Creative Commons Attribution 4.0 International License 


\section{<}

RI.pdf

MPU. (2020). Profil. Mpu.Acehprov.Go.Id.

https://mpu.acehprov.go.id/index.php/page/1/profil

MPU Aceh. (2011). Keputusan MPU Aceh Tahun 2011. Mpu.Acehprov.Go.Id/. https://mpu.acehprov.go.id/uploads/NOMOR_07_TAHUN_2011_KOPI_LU WAK.pdf

Muhammad Asadurrahman. (2019). HUKUM WARIS BEDA AGAMA (Studi Metode Istinbath Hukum Abdul' Aziz bin Baz, Abdullah Ahmad an-Na'im dan Huruf alQardhawi) [IAIN Tulung Agung]. http://repo.iaintulungagung.ac.id/id/eprint/10547

Syamsul Bahri. (2011). PENERAPAN KAIDAH-KAIDAH HUKUM ISLAM DALAM ISTINBATH HUKUM (ANALISIS KAJIAN DEWAN HISBAH/PERSIS). Kanun Jurnal Ilmu Hukum, 55(13), 59-74. www.jurnal.unsyiah.ac.id > kanun > article

Winarto, Y. (2020). MUI mengkaji fatwa game player unknowns battlegrounds pubg. KONTAN.Co.Id. https://nasional.kontan.co.id/news/mui-mengkaji-fatwagame-player-unknowns-battlegrounds-pubg

Jurnal At-Tafkir: Volume 13 Nomor 1 Tahun 2020

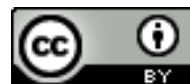

This work is licensed under a Creative Commons Attribution 4.0 International License 